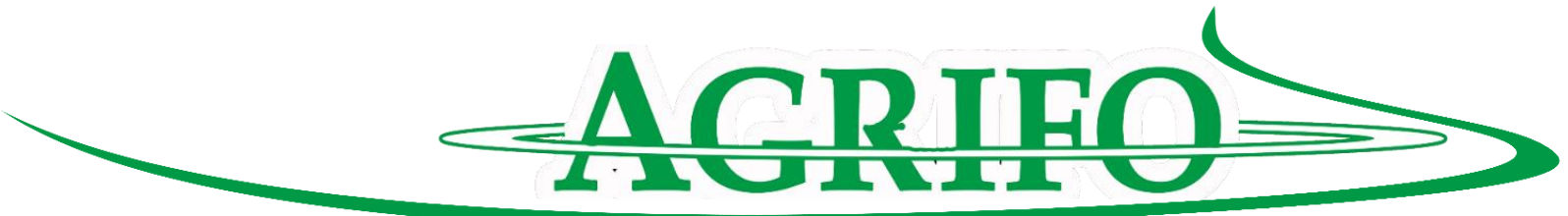

\title{
PERSEPSI MASYARAKAT NELAYAN TERHADAP PERANAN PANGLIMA LAOT DI KABUPATEN PIDIE JAYA
}

\author{
Eva Wardah ${ }^{1}$, Nasruddin ${ }^{2}$, Rosnina \\ email: eva.pwd@gmail.com
}

\begin{abstract}
ABSTRAK
Tujuan jangka panjang dalam penelitian ini adalah untuk mengetahui persepsi masyarakat nelayan terhadap peran panglima laot di Kabupaten Pidie Jaya. Secara khusus penelitian ini bertujuan untuk (1) Mengidentifikasi karakteristik masyarakat pesisir di Kabupaten Pidie Jaya Provinsi Aceh, (2) Mengetahui dan menganalisis peran Panglima Laot bagi masyarakat pesisir di kabupaten Pidie Jaya dalam pengelolaan sumber daya pesisir, (3) Mengetahui persepsi masyarakat pesisir terhadap peran Panglima Laot dalam pemberdayaan dan pelestarian lingkungan pesisir di Kabupaten Pidie Jaya.

Penelitian ini mengunakan metode survey dimana penentuan lokasi ditentukan secara purposive ( sengaja) di Kabupaten Pidie Jaya. Data pimer didapatkan dari responden melalui wawancara terstruktur (quisioner). Hasil penelitian menunjukkan bahwa masyarakat nelayan dilokasi penelitian mayoritas masih berumur produktif, tingkat pendidikan formal rata-rata SLTP serta pendapatan keluarga yang rendah. Masyarakat nelayan dilokasi penelitian masih berpersepsi bahwa Panglima laot masih berperan dalam kehidupan sosial masyarakat pesisir. Jenjang persepsi tersebut secara berurut adalah: 1) Peran Panglima Laot dalam menyelesaikan perselisihan dan persengketaan antar nelayan, (2) Peran Panglima Laot dalam mengawasi ketentuan hukum adat laot,(3) Peran Panglima Laot sebagai penghubung antara nelayan dengan pihak pemerintah dan (4) Peran panglima laot dalam menjaga dan mengawasi kelestarian lingkungan wilayah pesisir.
\end{abstract}

Kata Kunci; persepsi, peranan Panglima Laot, lingkungan , masyarakat pesisir

\section{PENDAHULUAN}

Provinsi Aceh sangat potensial untuk dikembangkan mengingat potensi wilayah dan lautan yang pengelolaannya masih mengacu pada kondisi ekosistem lokal setempat. Nilai budaya dan lembaga adat yang telah mengakar dalam masyarakat lokal telah terbukti mampu mengatur dan mengendalilkan anggota masyarakatnya dalam memanfaatkan dan mengelola sumberdaya yang ada dan juga dapat menciptakan keadilan diantara sesama masyarakat dalam usaha menjaga kelestarian sumberdaya alam yang ada. Hal ini mengakibatkan seringanya terjadi benturan atau konflik kepentingan antara keinginan atau program yang dilaksanakan pemerintah dengan keinginan dan kebiasaan masyarakat setempat.

Salah satu lembaga adat yang mempunyai peranan penting dalam pengaturan pemanfaatan dan pengelolaan sumberdaya pesisir dan kelautan adalah Lembaga Hukum Adat Laot yang dipimpin oleh seorang

\footnotetext{
${ }^{1}$ Staff Pengajar Program Studi Agribisnis Universitas Malikussaleh

${ }^{2}$ Staff Pengajar Program Studi Agroekoteknologi Universitas Malikussaleh Agroekoteknologi
} 
Panglima Laot . Lembaga ini berperan sebagai penguasa dalam pelaksanaan dan pengawasan terhadap aturan-aturan adat dibidang laut yang telah ditetapkan dan disepakati melalui musyawarah adat para pawang laot yang berdomisili di daerah tersebut.

Panglima laot yang merupakan pemimpin pada kelembagaan hukum adat laot pada hakekatnya memiliki potensi sebagai agen pembangunan yang selama ini kurang mendapatkan perhatian pemerintah untuk dilibatkan dalam pembangunan dan pemberdayaan masyarakat pesisir (nelayan), yaitu dalam mendukung terwujudnya masyarakat nelayan yang dinamis serta terjaganya kelansungan ekosistem wilayah pesisir. Panglima Laot juga memiliki tanggung jawab untuk mempertahankan hukum adat laut tersebut agar tetap dilaksanakan sebagai pranata sosial dalam masyarakat nelayan.

Penelitian ini bertujuan untuk; (1) mengetahui karakteristik masyarakat nelayan, (2) mengetahui peranan Panglima Laot bagi masyarakat nelayan, dan (3) mengetahui persepsi masyarakat nelayan terhadap keberadaan Panglima Laot dalam pemberdayaan serta menjaga kelestarian lingkungan di Kabupaten Pidie Jaya.

\section{METODE PENELITIAN}

Penelitian ini dilaksanakan di Kabupaten Pidie Jaya tepatnya di 2 (dua) Kecamatan yaitu Kecamatan Meurah Dua dan Kecamatan Ulim. Alasan pengambilan lokasi penelitian ini karena daerah ini merupakan desa pantai dan mempunyai Lembaga Hukum Adat Laot dipimmpin oleh Panglima Laot sebagai pelaksana hukum adat laot yang ada di daerah tersebut.

Populasi penelitian ini adalah nelayan perikanan tangkap yang berada dibawah Lembaga Hukum Adat Laot di
Kecamatan Meurah Dua dan Kecamatan Ulim yang masyarakatnya bermata pencaharian sebagai nelayan tangkap maupun nelayan budidaya. Sampel penelitian adalah masyarakat nelayan. Unit analis adalah individu masyarakat nelayan yang berfungsi sebagai responden. Data dikumpulkan dengan mengunakan daftar pertanyaan, wawancara yang mendalam, pangamatan langsung dan pengkajian terhadap data sekunder. Data sekunder yang dikaji meliputi buku-buku, laporan, jurnal hasil penelitian dan studi perpustakaan lain mengenai monografi desa, sosiologi masyarakat pesisir, dan sejumlah literatur yang ada relevansinya dengan penelitian ini.

Dalam pengisian daftar pertanyaan, jawaban responden di gali dari hasil wawancara yang berpedoman pada daftar pertanyaan. Pengamatan dilapangan dilakukan dengan terlibat aktif dalam kegiatan penjabaran peran Panglima Laot dan interaksinya dengan masyarakat nelayan. Kajian terhadap data sekunder dilakukan dengan mengambil data pada sumber data, yaitu : kantor desa, kantor statistik, kantor lembaga adat laot di tingkat propinsi dan tingkat kabupaten.

\section{HASIL DAN PEMBAHASAN}

Data yang dikumpulkan dalam penelitian ini di analisis dan hasilnya di interprestasikan untuk mencapai tujuan penelitian. Ada tiga tujuan penelitian yang hendak dicapai dalam penelitian ini, yaitu: (1) Mengetahui karakteristik masyarakat nelayan di Kabupaten Pidie Jaya, (2) Mengetahui peranan panglima laot bagi masyarakat nelayan di Kabupaten Pidie Jaya ,dan Mengetahui persepsi masyarakat nelayan terhadap keberadaan panglima laot dalam pemberdayaan serta menjaga kelestarian lingkungan. 
1. Distribusi Responden Menurut Sejumlah Karakteristik Terpilih

Karateristik Responden yang diamati dalam penelitian ini adalah: 1) umur, 2) pendidikan formal, 3) pendidikan non-formal, 4) besarnya pendapatan

\subsection{Distribusi Responden Menurut} Umur

Responden termuda dalam penelitian ini berumur 22 tahun dan tertua berusia 65 tahun. Dengan memperhatikan sebaran umur mereka maka responden dibagi menjadi tiga kelompok umur seperti nampak pada Tabel 1, yaitu : 1) Muda (22 - 30 tahun), 2) Sedang (31-40 tahun), dan 3) Tua (41-65 tahun).

Hasil penelitian tentang distribusi responden berdasarkan umur dapat dilihat pada Tabel 1.

Tabel 1. Distribusi Responden Menurut Umur

\begin{tabular}{llcc}
\hline No & Kelompok Umur & Responden & Persen \\
\hline 1 & Muda $(22-35$ tahun $)$ & 17 & $53.1 \%$ \\
2 & Sedang (36 - 50 tahun) & 9 & $28,1 \%$ \\
3 & Tua (51 - 65 tahun) & 6 & $18, .8 \%$ \\
& Jumlah & 32 & $100.00 \%$ \\
\hline
\end{tabular}

Tabel 1 menunjukkan dari 32 responden yang di wawancarai dalam penelitian ini separuh lebih sedikit yang berusia muda, lebih dari sepertiga berusia sedang dan selebihnya berusia tua.

Secara umum Tabel 1 menunjukkan bahwa masyarakat nelayan di lokasi penelitian masih termasuk ke dalam kelompok berusia produktif (usia kerja). Mayoritas anggota kelompok yang diamati berusia di bawah atau sama dengan 50 tahun. Sebagian kecil responden berusia lanjut (tua).

\subsection{Distribusi Responden Menurut} Tingkat Pendidikan Formal

Dalam penelitian ini tingkat pendidikan formal responden dibagi menjadi tiga kelompok, yaitu: 1) rendah, 2) sedang, dan 3) tinggi. Hasil penelitian tentang distribusi responden menurut pendidikan formal mereka dapat dilihat pada Tabel 2 berikut ini

Tabel 2. Distribusi Responden Menurut pendidikan formal

\begin{tabular}{llcc}
\hline No & Lamanya Pendidikan Formal & Responden & Persen \\
\hline 1 & Rendah $(0-6$ tahun $)$ & 12 & $37.5 \%$ \\
2 & Sedang $(7-9$ tahun) & 16 & $50.0 \%$ \\
3 & Tinggi (10 - 15 tahun ) & 4 & $12.5 \%$ \\
& Jumlah & 32 & $100.00 \%$ \\
\hline
\end{tabular}

Tabel 2 menunjukkan dari 32 responden yang diamati, mayoritas masyarakat nelayan berpendidikan rendah, sedangkan sepertiga berpendidikan menengah dan sebagian kecil responden yang berpendidikan tinggi.

\subsection{Distribusi Responden Menurut keikutsertaan dalam Pendidikan Non-Formal}

Pendidikan non-formal responden dalam penelitian ini dikategorikan menjadi dua yaitu; 1) tidak pernah, dan 2) pernah mengikuti baik 
pelatihan, kursus atau magang. Hasil penelitian tentang distribusi responden berdasarkan pendidikan non-formal dapat dilihat pada Tabel 3.

Tabel 3. Distribusi Responden Menurut keikutsertaan dalam Pendidikan Non-formal.

\begin{tabular}{llcc}
\hline No & Pendidikan Non-Formal & Responden & Persen \\
\hline 1 & Tidak pernah & 28 & $87.5 \%$ \\
2 & Pernah $\quad$ Jumlah & 4 & $12 ., 5 \%$ \\
& & 32 & $100.00 \%$ \\
\hline
\end{tabular}

Tabel 3 menunjukkan bahwa dari 32 responden yang diamati, hanya sebahagian kecil yang pernah mengikuti pendidikan non-formal, sementara selebihnya belum pernah mengikuti pendidikan non-formal.

$$
\text { Jadi mayoritas anggota }
$$
kelompok nelayan yang dilibatkan dalam penelitian ini tidak memiliki pengalaman mengikuti pendidikan nonformal untuk menunjang usaha mereka.

\subsection{Distribusi Responden Menurut Tingkat Pendapatan}

Besaran Pendapatan nelayan dihitung dari besarnya pendapatan nelayan dari kegiatan penangkapan ikan , maka responden dibagi menjadi dua kelompok, yaitu: 1) yang pendapatan dibawah Rp. $<1.500 .000$, 2) Pendapatan $>1.500 .000$. Hasil penelitian tentang distribusi responden menurut pendapatan nelayan dapat dilihat pada Tabel 4.

Tabel 4. Distribusi Responden Menurut Besarnya Pendapatan

\begin{tabular}{llcc}
\hline No & Besarnya Pendapatan (Rp/ bulan) & Responden & Persen \\
\hline 1 & $<$ Rp. 1.500.000,- & 28 & $87.50 \%$ \\
2 & $>$ Rp. 1.500.000,- & 4 & 12.50 \\
& Jumlah & 32 & $100.00 \%$ \\
\hline
\end{tabular}

Tabel 4 menunjukkan mayoritas nelayan mempunyai pendapatan diatas Rp. $<1.500 .000$ per bulan sedangkan hanya sebagian kecil nelayan memiliki pendapatan dibawah $\mathrm{Rp}>1.500 .000,-$ per bulan.

\section{Peranan Panglima Laot Bagi Masyarakat Nelayan di Kabupaten Pidie Jaya}

Pada dasarnya sesuai dengan ketentuan Lembaga Hukum Adat Laot (LHAL) yang dipimpin oleh Panglima Laot. Peranan Panglima Laot meliputi: (1) memelihara dan mengawasi ketentuan-ketentuan Hukum Adat Laot, (2) mengkoordinasikan dan mengawasi setiap usaha penangkapan ikan dilaut, (3) menyelesaikan perselisihan/sengketa yang terjadi diantara sesama nelayan atau kelompoknya, (4) mengurus dan menyelenggarakan upacara Adat Laot, (5) menjaga dan mengawasi agar pohonpohon di tepi sungai tidak ditebang, karena ikan akan menjauh sampai ke tengah laut, (6) penghubung antara nelayan dan pemerintah dalam melaksanakan program pembangunan perikanan, dan (7) mengatur jadwal acara-acara adat ritual yang berhubungan dengan masyarakat.

Peranan Panglima Laot yang disebutkan diatas mayoritas masyarakat nelayan dilokasi penelitian berpendapat tidak semua peranan tersebut dilaksanakan oleh Panglima Laot dan sudah mulai terjadi pergeseran dan penciutan dari sejumlah peran Panglima 
Laot baik yang disebabkan oleh kurangnya pengetahuan tentang lembaga hukum adat laot bagi nelayan maupun rendahnya kemampuan Panglima Laot dalam menjalankan peranan yang sesuai dengan amanat Lembaga Hukum Adat Laot.

Dari sejumlah peranan panglima laot tersebut mayoritas responden memberikan argumen hanya ada 4 (empat) peranan Panglima Laot yang masih dijalankan dilokasi penelitian dengan kadar pelaksanaan yang berbeda yaitu; (1) mengawasi ketentuanketentuan Hukum Adat Laot, (2) menyelesaikan peselisihan dan persengketaan antar nelayan, (3) sebagai penghubung nelayan dengan pihak pemerintah (4) serta menjaga dan mengawasi Lingkungan Pesisir.

\section{Persepsi Responden Tentang Peranan Panglima Laot}

Persepsi responden tentang peranan Panglima Laot dalam penelitian ini terdiri dari tiga butir; (1) peranan panglima Laot dalam mengawasi ketentuan hukum adat laot, (2) Peranan Panglima Laot dalam menyelesaikan peselisihan dan persengketaan antar nelayan, (3) peranan Panglima Laot sebagai penghubung antara nelayan dengan pihak pemerintah,(4) peranan Panglima Laot dalam menjaga dan mengawasi kelestarian Lingkungan Pesisir.

Hasil penelitian terhadap persepsi responden tentang peranan Panglima Laot ditunjukkan oleh Tabel 5 berikut ini.

Tabel 5 Rata-Rata Skor Persepsi Responden Tentang Peranan Panglima Laot Jumlah responden

Peranan Panglima Laot $(n=32)$

\begin{tabular}{lcc} 
& Jenjang & Rata-rata Skor* \\
\hline 1. Penghubung Nelayan dengan pihak pemerintah & 3 & 3.03 \\
2. Mengawasi Ketentuan Hukum Adat Laot & 2 & 3.20 \\
$\begin{array}{l}\text { 3. Menyelesaikan Perselisihan dan } \\
\quad \text { Persengketaan antar Nelayan }\end{array}$ & 1 & 3.39 \\
4. Menjaga dan mengawasi kelestarian & 4 & 2.87 \\
$\quad$ Lingkungan Pesisir & & \\
Rata-rata &
\end{tabular}

* Keterangan: (1) tidak setuju (2) kurang setuju (3) setuju (4) sangat setuju

Tabel 5 memperlihatkan bahwa, menurut persepsi responden terhadap peranan Panglima Laot yang utama adalah peran dalam menyelesaikan pesengketaaan antar nelayan. Persepsi masyarakat nelayan tentang peranan Panglima Laot ini ditempatkan pada jenjang pertama. Menurut hasil wawancara dengan nelayan dalam penyelesaain sengketa antara nelayan khususnya peselisihan dalam hal kegiatan perikanan tangkap Panglima Laot selalu aktif terlibat untuk mencarikan solusi dan memberiklan keputusan terhadap pihak-pihak yang bersengketa. Pada masyarakat nelayan bila terjadi sengketa maka pengaduan tidak langsung kepihak penegak hukum formal (kepolisian), namun dilakukan pengaduan dulu kepihak Hukum Adat 
Laot yang menjadi wilayah kekuasaannya yang dipimpin oleh panglima laot. Panglima Laot beserta perangkatnya meneliti dan mengkaji secara seksama untuk penyelesaian sesuai dengan hukum adat laot yang belaku. Misalnya sengketa perebutan wilayah tangkap yang berujung pada perkelahian antar nelayan. kondisi ini selaras dengan Eva Wardah, 2015, Fazriah Amfar, adwani mujibussalim 2015, panglima laot masih kuat perannya dalam menyelesaikan sengketa antara sesama nelayan dan pihak lain yang berkaitan dengan aktifitas penangkapan ikan pada masyarakat pesisir.

Bentuk penyelesaian adat yang difasilitasi oleh panglima laot tidak lepas dari ketentuan adat laot misalnya bila dari persengketaan/ peselisihan terjadi pertumpahan darah maka masingmasing pihak yang bersengketa dipertemukan dan didamaikan melalui kegiatan syukuran (bhs aceh; kenduri) dengan semua kebutuhan kenduri tersebut dibebankan kepada pihak yang bersengketa dengan porsi yang berbeda tergantung besar kecilnya kesalahan para pihak yang bertikai . dan hal ini sesuai juga dengan hasil penelitian Rahayu, S,W, 2014 dimana Panglima Laot menjadi alternatif lembaga penyelesaian sengketa dalam sistem hukum pada masyarakat pesisir di Provinsi Aceh.

Peran panglima laot yang berikutnya yang masih kuat dirasakan oleh masyarakat nelayan adalah menjaga ketentuan hukum adat laot misalnya berkenaan dengan hari pantangan melaut yaitu setiap hari jum'at dan hari raya idul fitri dan idul adha serta pantangan setelah kenduri laot. Mekanisme pengawasan yang dilakukan bersifat partisipatif dari seluruh nelayan. Bila ada yang melangggar ketentuan hari pantangan melalut maka siapun yang melihatnya melaporkan kepada panglima laot yang seterusnya panglima laot memanggil pihak tersebut untuk dimintakan klarifikasi. Bila terbukti melanggar maka panglima laot akan menyita hasil tangkapan dan diberikan sanksi tidak boleh melaut kepada yang melangggar dalam jangka waktu tertentu (maksimal satu pekan). Hasil tangkapan pihak yang melangggar ketentuan adat laot biasanya akan dilelang dan dana yang terkumpul biasanya dimanfaatkan untuk kegiatan lembaga hukum adat laot. Misalnya acara kenduri laot atau dijadikan dana operasional bila terjadi musibah dan pencarian nelayan yang hanyut atau tenggelam di laut.

Masyarakat pesisir juga mempersepsikan panglima laut juga aktif menjadi penghubung antaranelayan dengan pemerintah. Selama ini selain kepada pihak penyuluh perikanan nelayan juga mengadukan atau menyampaikan aspirasinya melalui panglima laot untuk diteruskan kepada pihak pemerintah misalnya berkenaan dengan permohonan bantuan armada dan alat tangkap kepada nelayan serta program pemberdayaan ekonomi masyarakat nelayan. Namun walaupun dipersepsikan demikian berdasarkan wawancara dengan panglima laot Kabupaten Pidie Jaya (Abdul Hamid) pihaknya selama ini kurang dilibatkan dalam merencanakan program dan pelaksanaan program pihak pemerintah dalam pemberdayaan masyarakat nelayan. Namun bila terjadi kekisruhan sering pihak lembaga hukum adat laot melalui panglima laot dilibatkan oleh pemerintah dalam penyelesaian masalah sehingga terkesan oleh nelayan panglima laot mampu menjadi penghubung antara nelayan dengan pihak pemerintah.

Peran panglima laot yang masih dianggap rendah oleh masyarakat nelayan diwilayah pesisir dalam hal menjaga dan mengawasi kelestarian 
lingkungan pesisir. walaupun ada himbauan yang dilakukan oleh pihak panglima laot untuk menjaga kelestarian alam wilayah pesisir namun dalam faktanya lapangan banyak masih ditemukan praktek-praktek perusakan dilingkungan pesisir misalnya menebang kayu bakau di sepanjang muara (kuala). Pelanggaran terhadap pihak yang tidak menjaga kelestarian lingkungan selama ini memang sangat sedikit yang diberikan sanksi oleh lembaga hukum adat laot sehingga ini diduga yang menyebabkan masyarakat mempersepsikan panglima laot masih kurang berperan dalam hal menjaga dan mengawasi kelestarian lingkungan diwilayah pesisir.

\section{KESIMPULAN DAN SARAN}

\section{Kesimpulan}

Berdasarkan hasil penelitian dan pembahasan, dapat di kemukakan beberapa kesimpulan sebagai berikut:

1. Karakteristik Umur masyarakat nelayan mayoritas berusia kerja yang produktif. Mayoritas nelayan mempunyai tingkat pendidikan formal yaitu Sekolah Menengah Tingkat Pertama (SLTP). Mayoritas nelayan belum pernah mendapatkan pendidikan nonformal yang berhubungan dengan usaha mereka. dan mayoritas nelayan memiliki pendapatan diatas $\mathrm{Rp}<1.500 .000$,perbulan.

2. Seiring dengan berjalannya waktu sejumlah peranan Panglima Laot yang sesuai dengan ketentuan Lembaga Hukum Adat Laot ( LHAL) pada masyarakat pesisir mulai terjadinya pergeseran dan penciutan peranan Panglima Laot baik yang disebabkan oleh kurang pengetahuan nelayan tentang keberadaan Lembaga Hukum Adat Laot maupun rendahnya kemampuan
Panglima laot dalam menjalankan peranan yang sesuai dengan amanat Lembaga Hukum Adat Laot.

3. Persepsi masyarakat nelayan pada umunnya Panglima Laot masih berperan dalam kehidupan masyarakat pesisir. Jenjang persepsi tersebut secara berurut adalah: 1) Peran Panglima Laot menyelasaikan perselisihan dan persengketaan antar nelayan, (2)Peran Panglima Laot mengawasi ketentuan hukum adat laot,(3) Peran Panglima Laot sebagai penghubung antara nelayan denga pihak pemerintah dan (4) Peran Panglima Laot dalam menjaga dan mengawasi kelestarian lingkungan wilayah pesisir.

\section{Saran}

Berdasarkan kesimpulan diatas maka dikemukakan beberapa saran sebagai berikut ;

1. Kegiatan pemberdayaan masyarakat nelayan untuk meningkatkan kesejahteraannya perlu dilakukan pembenahan-pembenahan

karakteristik nelayan mulai dari perhatian terhadap peningkatan pendidikan formal dan non-formal melalui penyuluhan dan pendampingan untuk meningkatkan ketrampilan dan kinerja dari nelayan.

2. Memposisikan panglima laot sebagai mitra pemerintah dalam menjalankan pembangunan disubsektor perikanan tanpa harus ikut campur dalam menentukan dan penunjukan sepihak oleh pihak pemerintah baik muspika kecamatan maupun dinas terkait terhadap individu yang akan menjadi penanggung jawab pelaksanaan hukum adat laot (Panglima Laot).

3. Masih sangat perlu dilakukan sosialisasi kepada nelayan tentang Peranan Lembaga Hukum Laot serta Peranan Panglima Laot kepada masyarakat nelayan sebagai lembaga 
yang sudah mengakar pada masyarakat nelayan di Nanggroe Aceh Darussalam yang mempunyai nilai lokalitas spesifik

\section{DAFTAR PUSTAKA}

Anonimous, 2003 Peranan Hukum Adat Laot/ Panlima Laot dalam Menyelesaikan Sengkata Nelayan di Nanggroe Aceh Darussalam. (makalah seminar pusat studi keamanan dan perdamaian UGM), Yogyakarta. , 2002 Keputusan Pertemuan/ Musyawarah Panglima Laot se Provinsi Nanggroe Aceh Darussalam, Banda Aceh. , 2000, Sistem pengetahuan kenelayanan di Kabupaten Aceh Besar, LAKA, Banda Aceh.

Eva Wardah. 2015. Peran Lembaga Hukum Adat Laot dalam mengatur Sistem bagi hasil Perikanan tangkap antara nelayan dengan Pemodal di Kabupaten Aceh Barat. Jurnal Acta Aquatica No. 2 Vol.2 Hal. 75-78 Prodi Budidaya Perairan Fakultar Pertanian Universitas Malikussaleh.
Fazriah Amfar, Adwani, Mujibussalim, 2015. Pelaksanaan Tugas dan Fungsi Panglima Laot di Sabang, Jurnal Ilmu Hukum,No, 4 Vol.3 Hal.13-19. Pasca Sarjana Universitas Syiah Kuala.

Hakim Nya' Pa .2002. Panglima Laot: Peranannya Dalam Lembaga Adat Laot (Menuju Hukum Adat yang Berkekuatan Tetap). Makalah Lokakarya dan Duek Pakat Adat Laot Oleh Panglima Laot Se-Aceh di Sabang, 19-20 Maret 2002.

Rahayu, S. W. 2014. Lembaga Penyelesaian Sengkata Adat Laut" Panglima Laot" Di Aceh sebagai bentuk Pengembangan Alternatif Penyelesaian sengketan Dalam sistem Hukum di Indonesia. Jurnal Hukum No.1 Vol.1 Fakultas Hukum, Universitas Padjajaran

Setia Budi 2007, Keberadaan Hukum adat Laot sebagai kearifan lokal dalam pengelolaan sumberdaya alam pada masyarakat pesisir Nanggroe Aceh Darussalam. Jurnal Agrium Fak. Pertanian Universitas Malikussaleh 2007. 